\title{
Print awareness of adult illiterates: a comparison with young pre-readers and low-educated adult readers
}

\author{
Jeanne Kurvers · Roeland Van Hout · Ton Vallen
}

Published online: 30 May 2008

(C) The Author(s) 2008

\begin{abstract}
In this study the print awareness of 25 unschooled adult illiterates in the Netherlands was compared with that of 24 pre-reading children and of 23 loweducated literate adults with approximately four years of primary schooling. The illiterates were interviewed about their experiences with writing and all participants completed six assessments of print awareness in the language they preferred (first or second language). The outcomes revealed that the three groups did not differ in distinguishing conventional written signs from other visual signs, that both groups of non-readers differed significantly from low educated readers but not from each other in knowledge of logos, inscriptions and knowledge of the written register, while the adult illiterates performed significantly better than the children on grapheme knowledge. Adult illiterates in literate societies seem to be well informed about the uses and functions of written language and about what writing looks like, but like young children they are not good at reading environmental print out of context and in explaining what exactly is represented in writing. The variation in reactions within the group of illiterate adults could be related to existing models of emergent literacy. Implications for adult literacy education are discussed.
\end{abstract}

Keywords Print awareness · Emergent literacy · Literacy acquisition · Illiteracy · Adult literacy

\footnotetext{
J. Kurvers $(\bowtie) \cdot$ T. Vallen

Faculty of Humanities, Tilburg University, Warandelaan 2, P.O. Box 90153,

Tilburg 5000 LE, The Netherlands

e-mail: j.j.kurvers@uvt.nl

T. Vallen

e-mail: a.1.m.vallen@uvt.nl

R. Van Hout

Faculty of Arts, Radboud University Nijmegen, Warandelaan 2, P.O. Box 90153,

Tilburg 5000 LE, The Netherlands

e-mail: r.w.n.m.vanhout@let.ru.nl
} 


\section{Introduction}

Emergent literacy of pre-reading children has been studied extensively over the last decades.

Starting in the seventies and eighties two strands of research have been productive and challenging in particular: studies on print awareness, i.e. the concepts young children develop about print and writing, and studies on language awareness of structural features of spoken language (Adams, 1990; Gombert, 1992, Morais \& Kolinsky, 2004, Teale \& Sulzby, 1987; Tolchinsky, 2004). We consider print awareness as a construct separate from language awareness (Sénéchal et al., 2001). Print awareness refers to the pre-reading stage of developing concepts about print and written language (Sulzby \& Teale, 1991; Tolchinsky, 2004), whereas language awareness refers to the ability to reflect on (spoken) language forms separately from their meanings (Francis, 1999; Gombert, 1992). The importance of studies on pre-reading children in relation to processes of reading and writing can hardly be overestimated (Chartier, 2004). Comparable research on another group of pre-readers, illiterate adults without any school history, however, did hardly emerge.

This study is about print awareness of illiterate adults without a school history. What do they know about writing? Can they recognize environmental print, such as inscriptions and logos? How do they think about the representational nature of writing? How do they judge features of the written register? Are the concepts and ideas they have constructed about print and writing comparable to what is known about the emergent literacy of young children?

Most studies in which 'illiterate' adults in Western countries were involved focused on adults who went to school in their childhood for quite some time but who were not successful in learning to read and write (cf. Barton, 1985; Greenberg, Ehri, \& Perin, 2002; Hunter \& Harman, 1979; Scholes, 1993; Scholes \& Willis, 1991; Viise \& Austin, 2005; Worthy \& Viise, 1996). Their phonological and orthographic problems and abilities and their print awareness cannot be generalized to the 'true' illiterates that are focal in this study: illiterate adult migrants who did not have a chance to go to school as a child to learn to read and write.

Our 'true' illiterate adults are non-readers, but theories about non-readers' conceptions of written language and about emergent literacy are built on studies with young children, a stage in life where language and cognitive development, and exposure to print go hand in hand. It is not clear, which conceptions should be attributed to the fact that the data come from young children in their course of development and which conceptions relate to the circumstance that the children are non-readers that did not experience formal reading instruction yet. Adult illiterates form an interesting testing case in this respect. Unlike young children they are experienced language users with many years of exposure to print (the age factor), and just like young children they have not experienced formal reading instruction (the literacy factor). If their conceptions of writing are quite different from those of young children, the age factor ought to be important in theories about emergent literacy. If, on the other hand, their ideas and concepts about writing are more similar to those of young pre-reading children, not being able to read seems to be the main factor to be included in theories about emergent literacy. So, we need 
comparative data on print awareness from both young pre-reading children and literate adults to draw the proper conclusions.

In addition, data on adult illiterates' print awareness can contribute to finding the answer in the dispute in adult literacy education about two different kinds of models on reading acquisition: stage models that stress the importance of explicit attention to the written code and maximal use of orthographic information in learning to read (Chall, 1999; Juel, 1991), and non-stage models like the whole language approach, which claim that learning to read is largely natural, spontaneous and effortless, given enough exposure to and practice with uses of written language (Goodman, 1986; Smith, 1992). An implication of the latter would be that adult illiterates, having lived in print-rich environments for quite some time, have built up a sight vocabulary of functional written language (Sabatini, 1999) and do not need the "explicit and systematic teaching" (Chall, 1999, p. 163) of how letters relate to sounds. An implication might also be that variation in knowledge about environmental print could be predicted by exposure to print in a print-rich environment. Therefore, it is worthwhile to investigate to what extent adult illiterates are able to understand environmental print and to compare their reactions to those of pre-reading children which, according to some studies, are not good in reading environmental print (Adams, 1990; Masonheimer, Drum, \& Ehri, 1986; Juel, 1991).

The primary aim of our study was to acquire knowledge about the print awareness of non-schooled adult illiterates, living in print-rich environments such as the countries in Western Europe. We especially wanted to investigate whether the ideas they have constructed about print are comparable to what is known from prereading children and to what extent their knowledge fits into models used to explain the print awareness of pre-reading children. To estimate adequately the print awareness skills of non-schooled illiterates, it was necessary to compare their performance and achievements to reference groups with the same ethnic and social background. We used, besides the illiterate adults, two reference groups for our comparison: non-reading pre-school children (in order to have two groups with the same level of non-literacy, but having a different age) and low-educated literate adults with approximately four years of schooling in the primary grades (in order to have two groups having the same age, but with a different level of literacy). A secondary aim of the present study was to inform educational practice. Since effective teaching should be built on the knowledge the students bring into the classroom, knowing more about what adults entering literacy courses know about letters, print or written language can help literacy teachers to adapt their teaching practices to the knowledge and skills of unschooled illiterate adults.

\section{Print awareness}

"Research demonstrates that in the process of becoming literate, children construct original and precocious ideas about the practices of reading and writing and about the formal features of writing systems and the resulting texts. These ideas are the building blocks for further learning" (Tolchinsky, 2004, p.11). Print awareness refers to knowledge about environmental print, knowledge of written signs and graphemes, and knowledge about relationships between speech and writing, which 
becomes manifest, for example, in respectively identifying inscriptions and logos, in being able to differentiate between pictures and graphemes, and in expressing concepts about how writing represents language. Several studies have shown what knowledge children develop in interacting with literate adults and in growing up in highly literate societal contexts. Children gradually learn to understand that writing represents speech directly, and become familiar with the specific features of the written register (Bialystok, 1991; Crone \& Whitehurst, 1999; Ferreiro, 1983, 1985; Ferreiro \& Teberosky, 1982; Gombert, 1992; Homer \& Olson, 1999; Ravid \& Tolchinsky, 2002; Sulzby \& Teale, 1991; Tolchinsky, 2004).

Confronted with environmental print such as inscriptions and logos, pre-reading children seem to memorize object and context as a whole. Once the visual contextual information is left out (such as the golden arches in the McDonald's logo), they lose their ability to name labels (Bialystok, 1991; Masonheimer, Drum, \& Ehri, 1984), and the ability to recognize environmental print seems to be unrelated to knowledge of letters and sounds (Blair \& Savage, 2006). Children develop already early some knowledge about differences in notational systems and seem to understand that written language requires special marks that are different from pictures (Brenneman, Massey, Machado, \& Gelman, 1996). Bialystok (1995) examined what young children know about the symbolic nature of letters. Based on Ferreiro and Teberosky (1982), she presented several forms of writing, pictures, and scribbles to the children and asked them if and by whom the symbols could be read. Five-year-olds knew more than four-year-olds, and many children seemed to know much about the forms and features of letters, but not about how they represent language. Homer and Olson (1999) asked young children to write words such as dog, two dogs or no dog. The children who thought that writing represents meaning directly, used one or two symbols to write $d o g$ or two dogs respectively, but refused when asked to write no dog because of the lack of a referent.

Gombert (1992) summarized the emergent print awareness of young children as a gradual development in thinking about writing as a pictographic system, in which signs share visual or quantifiable features with a referent, to writing as an ideographic system (in which signs are conventional, but represent an idea or concept) to, finally, writing as a grapho-phonological system, in which signs represent speech units. Many reviews of children's emergent concepts of writing assume early experiences at home and in pre-school to be the primary predictors of emergent literacy and the main source of the consistent differences found between children from different socioeducational levels or cultural groups (Adams, 1990; Gombert, 1992; Neuman \& Celano, 2001; Sulzby \& Teale, 1991). Thus far it is not known whether the concepts about print of unschooled illiterate adults are comparable to those of young children, how they think about what writing represents, how they deal with environmental print and whether their knowledge reflects what was found for young children.

\section{A comparative study}

Most theories on the development of print awareness of children suppose these skills to be dependent on exposure to print at home or in pre-school (Burgess, Hecht, \& Lonigan, 2002; Bus, Van Ijzendoorn, \& Pellegrini, 1995; Lonigan \& Whitehurst, 
1998), whereas knowledge about the nature of the relationship between writing and speech is expected to be influenced by formal instruction (Gombert, 1992, Olson, 1994, 1997; Kurvers \& Uri, 2006; Kurvers, 2007; Morais \& Kolinsky, 2004). What about illiterate adults, our focal group of non-readers? It seems self-evident that both groups of non-readers are expected to know less than low-educated adult readers, but that difference needs to be demonstrated. If adult illiterates might have built up a sight vocabulary, because "when language (oral or written) is an integral part of functioning of a community and is used around and with neophytes, it is learned 'incidentally'" (Antwergen, Flores, \& Edelsky, 1987, p. 152; see also Chall, 1999; Juel, 1991; Sabatini, 1999), their knowledge of environmental print might be more similar to low-educated adult readers. If, however, reading environmental print requires more processing of graphemic instead of only visual information like colours, their reactions might be more similar to those of young pre-readers. Therefore, we compared the print awareness of the adult illiterates with both prereading children and low-educated, but literate adults.

\section{Method}

\section{Participants}

The participants were predominantly unschooled illiterate adults, pre-school children before entering first grade and literate adults who had a mean of four and a half year of primary schooling. Since almost all native Dutch adults who cannot read or write have a history of formal education, illiterate adult migrants without former schooling, who had just entered adult literacy classes, were selected. As illiterates those adults were selected that had (a) no schooling at all or at most two years of primary education, and (b) could not read simple monosyllabic words they had not been practicing with (see below). Adults who could not read simple monosyllabic words, but had been to school for more than two years, were removed from the sample. As literates only adults were selected that that (a) had been attending school between two and seven years, and (b) were able to read a short text (see below), either in their mother tongue or in Dutch as a second language. The children selected were in the final term of kindergarten (a two-year period in the Netherlands that nearly all children attend before entering first grade), had not been in kindergarten for more than three years, and were to go to first grade in the next school year. Table 1 presents the backgrounds of the participants in the study.

Table 1 Participants by research group and ethnicity

\begin{tabular}{lrrr}
\hline Research group: & Children & Illiterate adults & Literate adults \\
\hline Ethnic group & & & \\
$\quad$ Moroccan & 14 & 14 & 11 \\
Turkish & 3 & 6 & 5 \\
Somali & 3 & 2 & 3 \\
Other & 4 & 25 & 4 \\
Total & 24 & & 23 \\
\hline
\end{tabular}


All participants came from medium-sized cities in the southern part of the Netherlands. The children were attending the last term of pre-school, all schools being so-called 'black' schools, which means that at least $60 \%$ of the school population was composed of immigrants to the Netherlands. The adult illiterates had started to take part in adult literacy classes, whereas the literates had started in classes on Dutch as a second language. Both classes were offered in the same neighbourhoods as where the schools of the children were located.

Of the 14 illiterate Moroccan adults, eleven spoke Tarifit, one of the Berber languages, as their mother tongue, and three spoke Moroccan-Arabic. Of the literate Moroccans, six were Tarifit speakers and five were Moroccan-Arabic speakers. Seven Moroccan children had Tarifit as their home language. All Somalis had Somali as their home language, and all Turks Turkish. The other participants were mainly children and adults from the former Dutch colonies of Surinam and Curaçao, and spoke both Sranan Tongo (Surinam) or Papiamentu (Curaçao) and Dutch at home.

The mean age of the children was 6.4 years, with a range from 5 to 7 . To be sure that the differences between the two groups of adults would not be caused by differences in their backgrounds, additional background data were gathered and checked. In both groups of adults, the majority of the participants were women (19 in both groups); the difference was not statistically significant (chi-square $(1, N=48)=0.32$, ns). In both groups, about half of the participants came from villages and the other half from smaller or larger towns (chi-square $(1, N=48)=0.09, \mathrm{~ns})$. Of the 25 illiterates, 15 lived with a partner and children in a one-family home (and the others with a partner, with children, alone, or with parents). The situation of the literates was similar; 12 of the 23 lived with a partner and children in a one-family home (chi-square $(1, N=48)=0.38$, ns). Twenty-two of the 25 illiterates and 17 of the 23 literates were unemployed (chi-square $(1, N=48)=3.68$, ns). In Table 2, some other relevant background data of the two groups of adults are presented, together with a test of significance.

As can be seen in Table 2, the mean age of the illiterates was 39, ranging from 15 to 57 , and the mean age of the literates was 34 , ranging from 17 to 55 . There was no difference between the groups in mean length of residence of the participants or their partners. Across both groups, the period of residence ranged from less than a year to more than 20 years. Of the 25 illiterate adults, 19 had never been to school as children, whereas six had attended some school for a short period of one or two years: Koran school (2 Moroccans, 1 Somali), a Swahili school in a refugee camp in Kenya (1 Somali), primary school (1 Turkish, 2 Surinamese). In all cases, not continuing primary education had reasons such as war, illness, girls who were kept home, distance to school or no money to pay for further school attendance. So, the chance that these six were illiterate because of having had severe reading problems, was small. The literate adults had attended primary school for on average four and a half years, ranging from two to six years of schooling.

Almost all illiterate and literate adults used their mother tongue more often at home than their L2 Dutch. As Table 2 shows, the majority of both groups preferred to speak the mother tongue and all literate and 20 illiterate adults reported (some) knowledge of another language, mostly Arabic or Dutch. Of those who did report any knowledge of a second language, 13 illiterates judged their knowledge of the second 
Table 2 Mean age, length of residence, length of residence of partner, years of schooling and language profile of illiterate and literate adults

\begin{tabular}{lllll}
\hline Background data & & $\begin{array}{l}\text { Illiterate } N=25 \\
M(S D)\end{array}$ & $\begin{array}{l}\text { Literate } N=23 \\
M(S D)\end{array}$ & $\begin{array}{l}\text { Difference } \\
t\end{array}$ \\
\hline Age & & $38.80(10.88)$ & $33.95(10.97)$ & 1.53 \\
Length of residence & $13.38(10.11)$ & $9.52(7.07)$ & 1.52 \\
Length of residence partner & & $16.04(8.55)$ & $17.31(6.87)$ & -0.48 \\
Years of primary school & & $0.40(0.76)$ & $4.61(1.34)$ & $-13.22^{* *}$ \\
Language profile & & $N=25$ & $N=21$ & $\chi^{2}$ \\
Home language most of the time & L1 & 23 & 20 & 0.23 \\
& L1 and L2 & 2 & 1 & \\
Preferred language & L1 & 19 & 14 & 0.49 \\
& Other & 6 & 7 & \\
Any L2 & No & 5 & 0 & $4.71^{\mathrm{a}}$ \\
Proficiency L2 & Yes & 20 & 21 & \\
& Little & 13 & 10 & 2.11 \\
& Reasonably well & 7 & 11 & \\
\hline
\end{tabular}

$* p<0.05, * * p<0.01$

${ }^{\mathrm{a}}$ Fisher exact, $p=0.054$

language as 'little', (e.g., "I can understand Dutch, but I cannot talk back"), the other 7 as reasonably well, For the literates who reported, these figures were 10 and 11 respectively. The groups did not differ significantly in these language profiles ( $\chi^{2}$ being $0.23,0.49,4.71$, and 2.11 , respectively), although reported knowledge of any second language was close to significance (Fisher exact $p=0.054$ ).

As an additional source of evidence to distinguish between readers and illiterates, next to their educational history, we administered a reading test that was used in adult education as an intake test for second language classes. The test consisted of a short text of about 150 words in short sentences in one out of 25 languages (e.g., Somali, Turkish, Arabic, and Dutch). The participants read the text aloud and told the experimenter what the text was about. Participants were judged literate if they could read the text aloud without sounding out most of the words and could indicate what the text was about. Adults with a history of schooling that did not pass this test were excluded from the sample (and were not added to the sample of illiterates, since they might have had reading problems). Twenty illiterates did not read anything at all, while five tried to decode and recognize some of the words. Eight of the literate adults read the text fluently, 13 reasonably well, while two of them needed some letter-by letter decoding with more complex words.

In addition to printed material that typically enters the post box in their households (bills, advertisements, information of local authorities), 22 of the illiterate adults mentioned the presence of some reading materials at home, mainly related to school (e.g., their own or children's homework) and to religion (e.g., the Koran). However, in general they reported much less printed material than is known from middle-class families (Adams, 1990; Heath, 1983; Neuman \& Celano, 2001). 
Thus, except for the difference in years of primary schooling and the ability to read, which were the focus of the present study, there were few differences in these background data between the two groups of adults. All except one of the illiterate adults had started literacy classes in Dutch as a second language. On average they had already attended these classes at the time of testing for about 60-80 h (about 3-4 months), ranging from about $20 \mathrm{~h}$ to about $200 \mathrm{~h}$, with each class meeting about 4-5 h a week. All literacy classes in Dutch as a second language start with a basic program in oral Dutch, preparatory exercises, and a gradual introduction of sight words and letters. After some months, about 50-60\% of the time is spent on oral skills, about $40-50 \%$ on reading and writing. Although there was variation in the hours they had already been attending the adult literacy classes, none of the illiterates was able to independently decode and recognize simple written words that they had not been practicing with during the lessons or they had learned as a sight word (i.e. no one learned to decode). All literates were attending second language classes in the same schools where the literacy classes were held. On average they had already attended these second language classes at the time of testing for about 9-10 months (two times a week for 2-3 h), ranging from three months to more than two years. All teachers used a communicationbased L2 method, in which about $50-60 \%$ of the time was spent on oral skills, $40-50 \%$ on literacy skills.

\section{Instruments}

\section{Interview experiences with written language}

To gather background data (all participants) and information about experiences with writing (adult illiterates) an interview guideline was developed. The questions were about early experiences with written language in their home country (Did you get any personal correspondence? Who did the reading and writing? Etc.), actual uses of written language and literacy-related activities (Can you write your name? Can you read prices of articles? Can you use the calendar?), help in using written language (Do you ask for help with reading and writing? Who do you ask? For what?), personal needs and aspirations (What do you want to learn?) and knowledge about functions and uses of writing (newspapers, advertisements, subtitling on TV, etc).

\section{Assessment instruments}

Research on print awareness (see the introductory section) revealed three different sub-domains to be especially relevant to investigate: knowledge of environmental print, knowledge of the writing systems and conceptions about the written register. Because none of these has been investigated with unschooled illiterates, we decided to include all three sub-domains. Table 3 gives an overview of these instruments, together with their internal consistency (Cronbach's alpha). 
Table 3 Overview of test instruments, number of items, and the internal consistency of the test instruments (Cronbach's alpha)

\begin{tabular}{llcl}
\hline $\begin{array}{l}\text { Print awareness } \\
\text { assessments }\end{array}$ & Test instruments & $\begin{array}{l}\text { Number } \\
\text { of items }\end{array}$ & $\begin{array}{l}\text { Cronbach's } \\
\text { Alpha }\end{array}$ \\
\hline $\begin{array}{l}\text { Environmental } \\
\text { print }\end{array}$ & Inscriptions & 18 & 0.99 \\
Writing system & Logos & 9 & 0.88 \\
& Graphemes & 34 & 0.97 \\
& Signs & 14 & 0.75 \\
& Writing/speech & 7 & 0.84 \\
Written register & $\quad$ correspondence & & \\
& Characteristics of & 12 & 0.79 \\
& written language & & \\
\hline
\end{tabular}

\section{Inscriptions}

Recognition of environmental print (street signs, shop names, billboards) is often used to assess the emergent print awareness of young children (Masonheimer, Drum, \& Ehri, 1984; Sulzby \& Teale, 1991). Illiterate adults are sometimes judged to be able to recognize environmental print, even when they are not able to decode (Antwergen et al., 1987; Sabatini, 1999; Smith, 1992). Thus, we used this assessment to determine whether illiterates would recognize written words, which are observable frequently in public areas. Eighteen frequent environmental inscriptions such as uitgang (exit), kassa (pay-desk) or gesloten (closed) were selected and presented in black and white letters, leaving out visual cues like color. The characters (i.e., upper case) were used as in the original inscriptions. The participants were asked to tell the researcher what the word meant. Either the name of the word (e.g., kassa), or indications of the meaning were accepted as correct (e.g., "Here you have to pay" for the word kassa). Indications of where the word was typically found (e.g. "I have seen this in the street") without any further explication were not accepted as correct. To investigate which features non-readers might use in recognizing environmental print, they were invited to explain their answers ("How do you know it says Exit?").

\section{Logos}

Like inscriptions, logos belong to environmental print. Logos make use of graphic cues (font, typeface), but also of visual, non-graphic cues, such as the 'swoosh' of Nikes or the yellow arches of McDonald's. In recognizing logos, young children seem to use the visual instead of the graphic cues (Masonheimer, Drum, \& Ehri, 1984). To investigate the influence of visual besides graphic cues in the recognition of environmental print, nine frequently used logos associated with places, services, brands, and so forth such as for postkantoor (post office) or McDonald's were presented with the same questions as in the inscriptions task. Selected were nine of the eighteen inscriptions, but now font, color, and visual context, such as the yellow arches, were preserved. Only the logos were presented as visual symbols on a piece of paper without any other contextual cues, such as the entrance of the whole shop or the street with the bus stop. The participants were asked to tell what the logo 
meant (What is this? What does it say here?). Either the name of the logo ("This means post office") or an indication of the referent ("This means the place where we go to send a parcel") was accepted as correct; i.e. the participant's broad indications ("This is a shop", "I have seen this in the city centre") were not accepted as correct. Participants were asked to clarify their answers ("How do you know it says Coca Cola?").

\section{Graphemes}

Grapheme knowledge is known to be one of the most important predictors of decoding ability (Adams, 1990; Bus \& Van IJzendoorn, 1999; Byrne, 1998). Verhoeven's (1992) standardized grapheme test was used to assess participants' knowledge of graphemes. The task consists of the 34 graphemes used in Dutch, eight of which are composed of two characters (e.g. oe, ie, $n g$ ). In this assessment participants were asked to identify orally the graphemes they knew. Both the sound of the letter (buh) and the letter name (bee) were coded as correct, but reactions such as "This letter is from my name" or "This is the letter of kar (cart)" were not. Participants who stopped after a few graphemes were encouraged to look carefully at all items, to be sure that no known items were omitted.

\section{Signs}

Even before they can read, children seem to have knowledge about specific features of print and to be able to distinguish between writing signs and other visual signs or symbols, such as geometrical shapes or drawings (Bialystok, 1995; Brenneman et al., 1996; Tolchinsky, 2004). To investigate the illiterates' knowledge of features of print, 14 cards with different visual signs or symbols (both referred to as signs from now on) were presented (based on Ferreiro \& Teberosky, 1982; Bialystok, 1995), and the participants were asked to sort out which ones were 'for reading' and which ones were not. The non-writing 'signs' were pictures (flower, fish), geometrical symbols (squares), or scribbles. In contrast to Bialystok's task, the writing signs were selected from different writing systems (Latin, Chinese, Arabic, Tamil). All participants got the same 14 items. Since adult readers might be expected to be able to differentiate between writing signs and other visual 'signs', this assessment was, as an additional check, conducted with only nine of the readers. A "for reading" answer for writing signs and a "not for reading" answer for all other signs was coded as correct, all other answers as not correct. Participants were invited to explain their choices ("I have seen this in the mosque").

\section{Writing/speech correspondence}

One of the major cognitive burdens for beginning readers is to understand how writing relates to speech (Olson, 1994, 1997) and to understand that the relationship between a written word and its meaning (e.g. the word flower) is different from the emblematic relationship between a drawing and its meaning (a drawing of a flower). 
Based on Ferreiro (1978; see also Homer \& Olson, 1999), a sentence (the same that Ferreiro used but in plural) and a word group (comparable to what Homer \& Olson used) were written on the spot, and the experimenter read them aloud while pointing to the words sequentially. For example, De kinderen spelen met de bal ('The children are playing with the ball'). Seven questions were asked, such as "Where does it say ball?" or "What does it say here? (pointing to children or the)", or "What else does it say here?" (pointing to a not yet questioned part of the phrase). Every answer in which the participant pointed to the word that was asked, or mentioned the word that was pointed to, were scored as correct. This task was not meant for the literates, since they could read what was written down. To check the latter assumption, this task was also conducted to five of the adult readers.

\section{Characteristics of written language}

The term writing not only refers to a specific code, but also to a specific language register, that differs from spoken language (Blanche-Benveniste, 1994). According to Ferreiro (1985) and Blanche-Benveniste (1994), many non-readers do not understand the written register in the way readers do. For example, they would reject false statements or improper grammar as 'writable'. Thus, in this assessment, we tried to determine the participants' conceptions of what can be written. Fourteen sentences were presented, of which 12 were grammatically correct, and two were not. Four sentences were either semantically anomalous (e.g., My mother is a man) or could be true, depending on the circumstances (It was raining yesterday). The participants decided whether these utterances could be written, and were asked to explain their answers. Agreements were scored as correct, denials as not correct if the participants denied again after a second question ("You are right, it was not raining yesterday. But could anyone nevertheless write that down?").

\section{Procedure}

Before the assessments started, some visits were made to the classes and the interviews with the adults were carried out. The researcher and one of the bilingual research assistants who were fluent in Dutch and either Tarifit, Turkish or Somali conducted the interviews. Depending on the preferred language of the participant either the mother tongue or Dutch was used. The Tarifit and Turkish assistant were postgraduate students in social sciences and linguistics respectively; the Somali assistant had been a teacher of Somali language. In all but two cases the background interviews were conducted in a separate room in the same building were the participants attended the lessons; with two participants the interviews were conducted at their homes. The background interviews took on average one and a half hour (ranging from one to two hours). All background data were collected before the assessments started.

All assessment data were gathered in two or three sessions of about one hour and a half, breaks depending mostly on the school timetables. All assessments were administered either in the mother tongue of the participants (Tarifit, Somali, Turkish) or in Dutch. Of the assessments with the Kindergarten children, 16 were 
administered in Dutch, 7 in their first language. For the illiterates these numbers were 20 and 5 for first and second language respectively and for the literates 12 and 11. Unless the participants refused (four illiterates and two literates did so) all assessments were audio taped and transcribed. The interviews with private information were not audio taped.

Analysis

All but six interviews and assessments were audio taped. Important results were obtained in the interviews with the illiterate adults, where they explain their personal histories, explain how they deal with their illiteracy, and how other persons help them to get information from written sources. For all assessments the responses of the participants were all transcribed in detail. The tapes and the transcriptions were used to categorize the responses of the participants, the primary categories being correct/incorrect or yes/no, depending on the assessment task, and a total score for each of the tasks was calculated. As mentioned, all assessments were carried out in either the first or second language of the participants, depending on their own preference. For the statistical analysis, we used the scores based on the yes/no or correct/incorrect categorization of the items in the instruments. We started with carrying out a two-way ANOVA (SPSS 11.0, GLM Univariate Analysis, model III) per instrument, the factors being group (three groups) and language (the language of the assessments, L1 or L2). We wanted to be sure that the effects of language and the interaction between group and language were statistically not significant or small enough to be left out in the further analyses. No interaction effects between group and language were found, and no main effect of language, except for one task. There was, besides a main effect of group, one statistically significant main effect of language, the assessment involving recognizing logos $(F(1,57)=6.99, p<0.05)$. Participants who were interviewed in Dutch recognized more logos than the participants who were interviewed in their mother tongues. This finding was probably an effect of length of residence: the participants who preferred Dutch were those who had been living in the Netherlands for more than ten or fifteen years. Given these outcomes (only one statistically main effect of language and no interactions), we decided to exclude language as a separate factor in subsequent analyses and to aggregate over languages. We continued with a one-way ANOVA (SPSS 11.0, GLM Univariate Analysis, model III), the factor being group (three groups), the dependent variables being the scores on the six assessment tasks. For Post hoc analysis we used Tukey HSD.

Can the explanations the informants gave about their answers provide us with a better insight in their print awareness? And can subgroups of items in the assessments tasks tell us more about the print knowledge of illiterates and prereading children? All explanations the participants gave for their answers during the assessments were notified and categorized, i.e. if they use visual instead of graphic information in recognizing logo's or inscriptions. Since the participants did not explain all answers (and for practical reasons were not asked to do so for every single item) these explanations were not quantified and analyzed statistically, but their comments, arguments and reflections were used as additional, supportive 
illustrations and sources of evidence in the analysis. The outcomes of these analyses are reported in the last part of the results section.

\section{Results}

The focus of this contribution is on the assessments concerning print awareness on the three sub domains, but to put the results in context, we start with the main outcomes of the personal interviews, that were conducted with the illiterates about their experiences and practices with writing.

Sixteen of the adult illiterates could not remember any concrete example of use of written language they were involved with as children, three others remembered looking at what their siblings (mostly brothers) were reading, while the six who had experienced a short period of schooling remembered, for example, some words or letters they had learned. Nineteen participants remembered somebody who was able to read personal correspondence to them, in almost all cases a relative or neighbour, while two remembered the postman reading letters to their families. Except for one widowed woman, all illiterate adults at that moment had at least one reader/writer in their immediate family, mostly their partner or one or more of their children and the relatives are the ones in charge when help is needed. All illiterate adults had a fairly good idea of the functions and uses of literacy. They knew the purpose of a newspaper, they knew about subtitling on television, they knew the uses of bills and billboards, and most of them knew the working of a calendar, agenda, or phonebook, although it seemed that the majority did not and could not use these tools themselves without help of relatives. Kachoura for example showed her insurance card and pointed to the place were her birth date should be written. This turned out to be the card-number. Mohammed showed how he distinguished his bankcard from another one, pointing to the three blue stripes that were there. When asked what they wanted to read, nineteen referred to functional reading and writing (advertisements, special offers and prices, bills, subtitling on television, news in the newspaper, school reports about the children, bank accounts), seven referred to personal correspondence from relatives abroad, and two explicitly mentioned the Koran. Reading a book was mentioned once. The illiterates knew they had insurance cards and identification cards, although some did not know where to look for specific information such as a birth-date. All but three of the illiterate adults could write their first names, although six not without mistakes, and only a few could write their surname or address as well. Sixteen of them had learned these skills recently in the literacy classes, the others told that a relative or the Koran teacher had taught them, or that they had learned to write their name themselves. In talking about reading, they nearly all made a clear distinction between looking and reading ("I can look at the newspaper, but I still do not know what it says"). The difference between learning to read and learning a (second) language, however, seemed confusing (e.g., some assumed they would be able to write letters to friends in Morocco once they had learned to read and write in Dutch). None of them could read simple monosyllabic words they had not already been taught, although three tried to sound out some words. 
All but three illiterate adults were determined to learn to read and write. For example, they made comments such as, "Otherwise I will stay like a blind person, who can look at the newspaper, and still do not know what it says" or "You are not a human being if you cannot read." Most illiterate adults expressed a low level of aspiration for their own future. For example, when asked what they wanted to learn in the second language literacy class, they gave answers such as "Just reading and writing" or "One level up, some more Dutch to answer the phone", while a few wanted more, such as attending vocational training or a computer course. In a discussion with the teacher after finishing the interviews, one of the participants told: "Later on, I am going to write a book about my life." "Why later? Why not now?" the teacher asked, "Right now, I do not have enough letters."

In short, all illiterates made use of written language with the help of readers/ writers in their environment and all could mention several, predominantly pragmatic functions of written language, such as their own home-work, advertisements or newspapers.

The results of the assessments task for the three groups investigated can be found in Table 4.

The table gives the means and standard deviations of the six tasks on print awareness. One-way analyses of variance were performed to test group differences. The resulting F ratios (one way analyses of variance; SPSS 11.0, GLM Univariate Analysis, model III), their significance, and the Eta squared values are also reported in Table 4.

As could be expected (one of the groups consisted of readers), the main effects of group were statistically significant for all assessments, although the Eta value was not high for the signs-task. In some of the assessments, the mean scores of the pre-reading children were higher than those of the adult illiterates (logos, sorting signs, written register), whereas in other assessments the mean scores of the illiterates were higher than those of the pre-reading children (inscriptions, graphemes, correspondence writing-speech), although in the average score for

Table 4 Means, standard deviations of scores, and statistical values for the six print-awareness tasks by group

\begin{tabular}{|c|c|c|c|c|c|c|c|c|c|}
\hline & \multicolumn{2}{|c|}{ Children } & \multicolumn{2}{|c|}{ Illiterate adults } & \multicolumn{2}{|c|}{ Literate adults } & \multirow[t]{2}{*}{ df } & \multirow[t]{2}{*}{$F$-ratio } & \multirow[t]{2}{*}{ Eta } \\
\hline & $M$ & $S D$ & $M$ & $S D$ & $M$ & $S D$ & & & \\
\hline Inscriptions (range 0-18) & 0.05 & 0.22 & 0.48 & 1.12 & 16.35 & 4.07 & 2,63 & $329.62 * *$ & 0.91 \\
\hline Logos (range 0-9) & 3.35 & 1.90 & 2.50 & 1.64 & 7.83 & 2.31 & 2,57 & $45.35 * *$ & 0.61 \\
\hline Graphemes (range 0-34) & 4.91 & 6.37 & 19.76 & 7.40 & 31.30 & 3.98 & 2,61 & $97.04 * *$ & 0.75 \\
\hline Signs (range $0-14$ ) & 11.63 & 2.67 & 10.71 & 1.99 & 13.00 & 1.12 & 2,42 & $3.24 *$ & 0.13 \\
\hline Correspondence (range $0-7)^{\mathrm{a}}$ & 2.88 & 1.90 & 5.00 & 2.14 & 7.00 & 0.00 & 2,32 & $10.89 * *$ & 0.39 \\
\hline Written register (range $0-12$ ) & 9.40 & 2.56 & 8.38 & 1.99 & 11.06 & 0.97 & 2,47 & $9.13 * *$ & 0.27 \\
\hline
\end{tabular}

\footnotetext{
a $n=5$ for the literate group

$* p<0.05$; ** $p<0.01$
} 
Table 5 Pairwise comparisons of print-awareness tasks (Tukey HSD)

$* p<0.05, * * p<0.01$

\begin{tabular}{llll}
\hline Task & $\begin{array}{l}\text { Child- } \\
\text { illiterate }\end{array}$ & $\begin{array}{l}\text { Illiterate- } \\
\text { literate }\end{array}$ & $\begin{array}{l}\text { Child- } \\
\text { literate }\end{array}$ \\
\hline Inscriptions & $\mathrm{ns}$ & $* *$ & $* *$ \\
Logos & $\mathrm{ns}$ & $* *$ & $* *$ \\
Graphemes & $* *$ & $* *$ & $* *$ \\
Signs & $\mathrm{ns}$ & $\mathrm{ns}$ & $\mathrm{ns}$ \\
Writing-speech & $* *$ & $*$ & $* *$ \\
$\quad$ correspondence & & & $*$ \\
Written register & $\mathrm{ns}$ & $* *$ & \\
\hline
\end{tabular}

writing-speech correspondence, the scores for those who refused the task are not included. ${ }^{1}$

In Table 5, the outcomes of the post hoc analyses (Tukey HSD) are reported. These were used to analyze the differences per pair of groups.

The post hoc analyses, the outcomes of which are shown in Table 5, revealed that both groups of non-readers differed significantly from the literate adults in all tasks except signs ( $p<0.05$ for written register, $p<0.01$ for all other tasks). This is hardly surprising, since one of the groups consisted of readers. More interesting therefore are the differences between the two groups of non-readers. Post hoc analyses revealed statistically significant differences between children and illiterate adults for graphemes and for writing-speech correspondence $(p<0.01)$. This might partly be explained by the fact that six illiterates had been to school for about a year and that nearly all illiterate adults had already started a literacy course, in which the first letters had been introduced and in which oral reading by the teacher, together with the pointing out of words, was regularly practiced. In the next section we analyze this further.

In short, in all assessments except knowledge of signs, the non-readers differed significantly from the readers. In most of the tasks, the two groups of non-readers did not differ significantly from each other, and if they did, learning experiences thus far seemed to be the main reason.

To illustrate the relative positions of the three groups in a straightforward way, $\mathrm{z}$ scores were computed for each task, which put the outcomes on a scale with a mean value of 0 and a standard deviation of 1 . By using standardized $z$ values, a direct comparison can reveal whether the tasks show a similar pattern of differences among the groups. Figure 1 presents a graphic overview of the mean z scores by group for all the print-awareness tasks.

Figure 1 makes clear that there are two general patterns. Four of the six tasks follow the same pattern, which mainly differentiates between readers and nonreaders, while in two tasks the illiterate adults were somewhere between children and literate adults. Figure 1 illustrates that, in four of the six tasks, the children did not differ from the illiterate adults (although the mean $\mathrm{z}$ scores of the children were

\footnotetext{
1 We did run the analysis with three illiterates that had been to primary school left out of the sample. All outcomes were nearly the same (all but one average a little bit lower). The analysis of variance and posthoc analyses revealed the same outcomes we present here.
} 


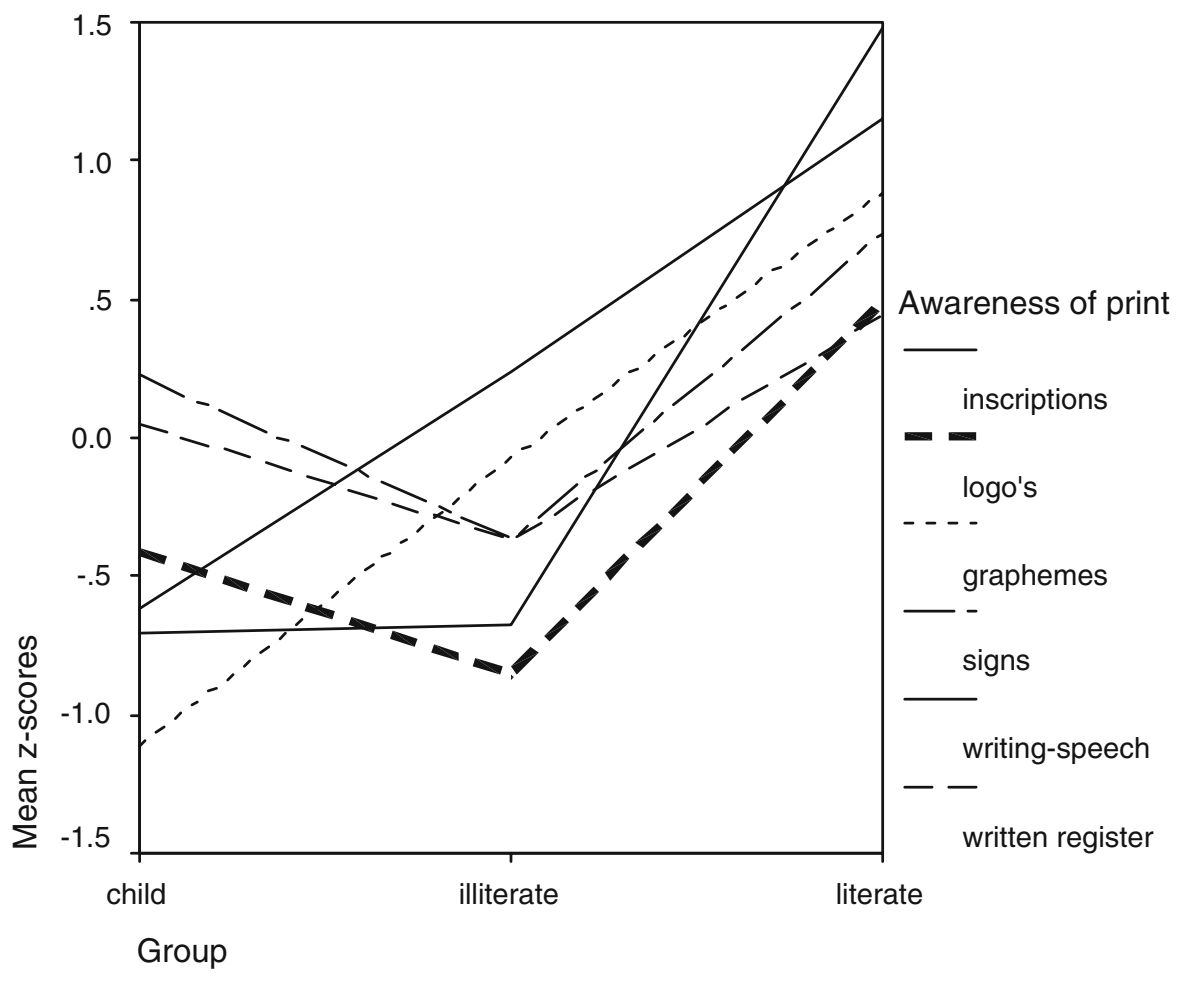

Fig. 1 Mean z-scores print awareness tasks by group

somewhat higher), while in two of the tasks (grapheme knowledge and writingspeech correspondence), they did, although in the correspondence task the outcomes of the illiterates will be somewhat flattered since four of them (who would probably have scored low) refused to carry out this task. The scores of both groups of nonreaders do not support the idea that they had succeeded in reading environmental print, simply as a result of being exposed to it for some time (the children) or even for many years (the illiterate adults).

Can we better explain the differences in performance between and within the two adult groups? To further relate the outcomes to the background data, we calculated first a total literacy score based on the percentage of correct answers over all tasks (11 of the 15 intercorrelations, all positive, between the measures were significant at $p<0.05$ ). The average score of the pre-reading children was 39.64 (SD 12.91), of the adult illiterates 47.19 (SD 10.23) and of the adult readers 91.74 (SD 11.47). As could be expected, the difference between the groups is significant $(F=133.73$, $p=0.000$ ), and posthoc analyses revealed that both groups of non-readers differed significantly from the adult readers (in both cases $p=0.000$ ), but not from each other. The difference between pre-reading children and adult illiterates is not significant $(p=0.08)$. To investigate the assumption that higher scores of the adults were more strongly related to earlier experience with education than to background 
data like age or period of residence in a highly literate society, we calculated (only for the adults) correlations with years of primary school, age, years of residence, and months of adult education lessons. Besides the high and significant correlation with years of elementary education that could be expected $(r=.82, p=0.000)$, the correlation with months of adult education lessons turned out to be significant as well $(r=.55, p=0.00)$, while the correlations with age $(r=-.11)$ and years of residence $(r=-.15)$ were not. We performed a stepwise regression analysis to detect the possible influence of the role of the separate background variables. We used the total literacy score as dependent variable and years of schooling in the country of origin, months of second language lessons, age and years of residence as predictor variables. Table 6 presents the outcomes of the final model.

Table 6 shows that the main explanatory variable is number of years of primary schooling, confirming the validity of the distinction we made between literate and illiterate adults. It is the first variable that was selected in the regression analysis and it remained the most important one after the inclusion in the regression of the second relevant variable, months of L2/literacy lessons. Age and residence did not pass the selection criterion $(F$-in 0.05$)$ and were excluded as predictor variables. The percentage explained variance is high $(70 \%)$. The outcome means that, next to years of primary education, a significant part of the differences between the adults (within the groups as well) can be explained by the amount of months of language lessons they had in the Netherlands.

Did the explanations the informants give about their answers provide us with a better insight in their print awareness? And are there relevant subgroups of items? As can be seen from Table 4, neither children nor illiterate adults were good in reading environmental print, i.e., inscriptions and logos such as Exit and McDonald's. Like young children, illiterate adults living in print rich environments did not recognize environmental print taken out of its original context. They recognized hardly any inscription and only a few logos. Further analysis revealed that logos with additional visual features, such as the yellow arches of McDonald's, or the colours and curls of the $C \& A \operatorname{logo}$, were significantly better recognized by the two groups of non-readers than logos with only color and type face as distinctive features, such as Hema and Edah (paired $t$-test, $t(39)=6.83, p<0.00$ ). This outcome is supported by the explanations most of the participants, both children and adult illiterates gave. "I can see that here", said Fatma, pointing at the yellow arches, when asked how she knew it said McDonald's. Since the two groups of

Table 6 Results of the stepwise regression analysis literacy score adults

\begin{tabular}{lllllll}
\hline Variable & $B$ & $\mathrm{seB}$ & $\mathrm{Beta}$ & $R^{2}$ & $t$ & $\mathrm{Sig}$ \\
\hline Included variables & & & & & & \\
$\quad$ Years of schooling home country & 7.35 & 1.00 & 0.699 & 0.70 & 7.34 & 0.000 \\
$\quad$ Months lessons Netherlands & 2.77 & 1.07 & 0.245 & & 2.57 & 0.014 \\
Excluded variables & & & & & & \\
$\quad$ Age & & -0.016 & & -0.16 & 0.87 \\
$\quad$ Years of residence & & -0.003 & & -0.37 & 0.72 \\
\hline
\end{tabular}


non-readers hardly recognized any inscription, no further analysis of this task is presented.

The illiterate adults knew significantly more graphemes than the young children did. Three of the illiterates knew less than ten graphemes, while only three children knew more than ten graphemes. One child and one illiterate knew nearly all graphemes. Further analyses at item level revealed that the graphemes with the highest recognition score $(s, m, r, a a, o o, v, j, k)$ all belonged to the first words that were introduced in the adult literacy course to start decoding. Therefore, it might be assumed that the scores of the illiterates reflect their learning experiences thus far (children did not learn letters in Kindergarten). An error-analyses revealed that the illiterates made the same types of mistakes as the young children did; the most frequently observed mistakes were confusing letters with partly similar shapes such as $b$ and $d$, or naming a letter by using a word they had just learned: "This is from meel (=flour)", "This is the letter of tak (=branch)", or "This is the letter of my name". Confusing letters with figures (a $g$ was called a 9) was observed incidentally among adult illiterates and more frequently among children.

The illiterate adults also performed better at the correspondence writing-speech assessments than the pre-reading children. The illiterates answered on average five of the seven questions correctly ( $S D$ 2.14), the children about three ( $S D$ 1.90). As expected, the five literates who conducted this task answered all questions correctly. The results of the illiterates, however, may be overestimated, because four of them refused to undertake this task: "How can I answer your questions? I cannot read yet." The probably low scores of these four might have eliminated the difference with the pre-reading children. Ten of the illiterate adults could point correctly to all content words and several of the other words (mainly using the first letter as an indication), while especially four (plus probably the four who did not take this test) seemed to be confused about how language is represented in speech. Observations suggest that the first letter of a word is an important cue for the illiterates. Kachoura, for example, pointed to the first letter of Kachoura when asked how she knew this was her name (later on she thought the word Kamer also indicated her name). Difan correctly pointed to çocuklar, and explains: "Because it says ç here". Error-types seem to be similar to what was found in young children. Four illiterates supposed a single slot could represent the whole sentence (e.g. at the place of the word children it said: "the children are playing"), and two illiterates supposed the word outside to be part of the sentence. Function words such as the were often not given a separate position in the written sentence (e.g. when asked what is written at the position of the word ball, Halide answered: "It says 'with the ball' here") Two of the illiterates thought that the words in the word group 'the three goats' represented respectively a goat, a goat and a goat.

In the signs-task both writing signs and other visual signs such as drawings and geometrical shapes were used. Further analyses with different item-types revealed that the groups did not differ in identifying writing signs as "for reading" ( $81 \%$ correct by the children, $84 \%$ by the illiterates and $89 \%$ by the literates); the difference between the groups was not significant (Fisher Exact 0.42, $p=1.00$ ). The difference between the groups in answering "not for reading" to the nonwriting signs, was more substantial (scores ranging from $61 \%$ by the illiterates to 
$85 \%$ by the literates) but again the difference was not significant (Fisher Exact 2.48, $p=0.30$ ). The non-readers (both children and illiterates) seemed to have a rather clear idea of which signs belonged to written language and which did not. For example, more than half of the illiterates (56\%) correctly identified Chinese characters as writing signs ("These are the letters of the Chinese restaurant"); all except two illiterate adults (nearly all were Muslims) correctly identified Arabic letters ("These are from the Koran", "My sister-in-law can read this") and written Tamil was often (87\%) identified as writing as well. Five of the children confused pictures with writing. Of the illiterate adults only one interpreted 'to read' as 'to know what it means' and identified all pictures as 'for reading' and all other signs as not for reading. Most of the 'errors' made, both by children and adult illiterates, concerned the scribbles ( $71 \%$ correct). They were identified as 'adult writing' by ten children and as specific handwriting by five of the illiterate adults ("This is the doctor's writing", "This is a receipt").

In the written register task, further analyses at item level revealed that the groups did not differ in admitting that both true and grammatically correct sentences could be written (percentages correct $84 \%, 88 \%$ and $100 \%$ respectively for children, adult illiterates and adult readers). Most of the participants at first stated that untrue utterances ("A baby is very old") could not be written, but 20 of the illiterate adults stuck to this opinion at further questioning ("You are right, this is not true. But even then, do you think someone could write this down?"), while the readers did not and admitted it could be written (although some of them added that there was no use in doing so). The average correct score for false statements (maximum score $=2$ ) for the children was 1.33 ( $S D$ 0.72), for the illiterates 0.43 ( $S D 0.68)$ and for the literates 1.59 ( $S D$ 0.62). Further analysis with group as between subject factor and sentencetype as within-subject factor revealed, besides a statistically main effect of group, a statistically main effect of sentence type $(F(1,50)=7.08, p=0.01)$ and a significant interaction between group and sentence type $(F(2,50)=5.00$, $p=0.01)$. This conclusion is supported by the arguments the participants added for other items as well. Truth was the most frequently used argument that almost all illiterate adults used in admitting that an utterance could be written. All admitted that I live in the Netherlands could be written, "Because that is true." Four were sure that $I t$ was raining yesterday could not be written, "Because it was not raining yesterday", while one person answered, "If it was raining yesterday, you could write this". The names of objects and figures such as television or two hundred could be written, but illiterate adults seemed to hesitate about more abstract words, according to explanations such as: "You can write 'tree', but you cannot write 'outside" ". Some others gave additional examples of language that could not be written, mainly variants of untrue statements, but also dirty words, impolite sayings or gossip. The children used the argument of truth as well, but less often. They more often seemed to have a powerful adult in mind that could simply write everything the researcher suggested ("My teacher can write everything"). Two children report another reason for confirming everything can be written: "there are enough letters", Hamed argues, although later on he starts hesitating and asks: "How many letters are there anyway?" 


\section{Conclusions and discussion}

The primary aim of this study was to acquire knowledge about the print awareness of non-schooled adult illiterates, living in print-rich environments such as the countries in Western Europe. We investigated them in a comparative study with a control group of pre-school children just before entering the first grade of elementary education and a control group of low-educated literate adults with an average of four and a half year of primary schooling. All groups had the same ethnic and social background. To assess the print awareness of the participants, their responses to six assessment tasks were collected. Additionally, interviews were conducted with the adult illiterates about their backgrounds and experiences with written language.

In the interviews, the illiterate adults mainly reported knowledge of the pragmatic functions and uses of written language. They mentioned pragmatic functions such as reading newspapers, subtitling on television, and advertisements, or writing messages to their children's teachers, and religious functions such as reading the Koran. Only two of them explicitly mentioned functions related to individual expression. Their ideas about the uses and functions of writing confirmed what Heath (1983) found in her Tracton and Roadville study.

The assessment tasks included the domains of knowledge of environmental print, of the writing system and of the written register. We summarize the conclusions per domain.

\section{Environmental print}

The results of the environmental print tasks suggest that the adult illiterates cannot recognize simple environmental print when the original context is lacking. They only recognize some logos with apparent visual (such as yellow arches) instead of graphic features (such as letters). In these tasks their outcomes were similar to those of the pre-reading children. Adult illiterates living in a highly literate environment for quite some time do not seem to learn to read and write without any systematic instruction, as sometimes has been suggested (Goodman, 1986; Sabatini, 1999; Smith, 1992). Studies among young children (Blair \& Savage, 2006; Juel, 1991; Masonheimer, Drum, \& Ehri, 1984) revealed that recognition of environmental print is, if it occurs, based on visual and not on orthographic features. We only can conclude that the same is true for non-schooled adult illiterates.

\section{Writing system}

The illiterate adults in our study knew more graphemes than the pre-reading children, although both groups differed significantly and negatively from the literate adults According to the letters they did know, this difference seemed to be an effect of attending adult literacy classes. The outcomes on the signs-tasks revealed that the illiterate adults knew quite well what written language looks like. Like young children, they are able to distinguish conventional written signs from other visual symbols such as pictures or geometrical shapes, and both groups of non-readers did 
not differ significantly from adult readers. In both groups of non-readers only a few participants seemed to confuse writing signs with other visual symbols.

The adult illiterates know better than young children about how writing relates to speech (although their ability might have been overestimated), but significantly less than low-educated readers and there is a notable variation in their level of knowledge about writing. Although this study was not meant to be developmental, different types of reactions within the group of illiterates could be traced that seem to reveal similar patterns in reactions as in the developmental stages that Ferreiro (1985) and Homer and Olson (1999) found in young children: ranging from a conception in which each word in a written sentence represents the objects that are mentioned to a conception in which an unanalyzed utterance is related to an unanalyzed written string, and finally up to the stage of the beginning reader who knows that each writing sign represents a speech segment. The answers and explanations of the participants on this task revealed that a few of them assumed that there was a direct countable correspondence between written signs and referents (for example when thinking that the three words in the sequence the three goats represented the three goats), while more than half of them knew on a global and unanalyzed level that writing represents spoken language. According to the answers that were given frequently, content words such as nouns or verbs can be written, grammatical elements such as prepositions or articles less so. This seems to correspond to a conception in which writing primarily represents speech events on a more global level.

\section{Written register}

The adult illiterates, like the young pre-readers, did differ from the adult readers in their conceptions of the written register. Although the illiterate adults differed in their views of what can and cannot be written, they nearly all assumed that what could be written needs to be true, and besides that, needs to have some status as well (gossip and dirty words were among the examples they gave of language that could be used orally, but not be written down). Their ideas about written language resemble what Blanche-Benveniste (1994) so nicely described as 'Sunday' language.

The outcomes together lead to the general conclusion that what writing looks like from the outside and what it is used for did not seem to pose problems for most of the illiterate adults, as the interviews about their experiences and the outcomes of the signs-task revealed. They know better than young children where writing is used for and in this respect they are more similar to low-educated literates. This outcome seems to confirm that being literate or not is not a matter of dichotomy (Koch, 1997; Wagner, 1993). The illiterate adults we investigated resemble what Koch (1997) called 'quasi-literates': they manage to participate in the literate community without being able to use the written medium themselves as could be inferred from the interviews. They can do so by relying on literate relatives or peers around them, who take care of the reading and writing that is relevant in their daily lives.

When it comes to the inside of written language, as for example the building blocks of the writing system and the relationship between writing and speech, the 
majority of the adult illiterates was more like the pre-reading children: they did not know exactly how writing represents speech, what is written at which place in a sentence, nor that every single part of a spoken utterance can be reduced to writing. The differences in this specific domain of print awareness (i.e. how writing relates to speech) that were found between the illiterate adults and the pre-reading children can be attributed to previous schooling: unlike the pre-reading children, six adults already had a short period of schooling and all except one already had started a literacy course. In that respect, our study on the print awareness of illiterate adults confirms the findings of Crone \& Whitehurst (1999) among young children: The impact of schooling is much larger than the impact of age (or period of residence in this case).

Our findings on the print awareness of the illiterate adults, in comparison to prereading children and literate adults appear to reveal a pattern that was found in research on the emergent literacy of children (Bialystok, 1991, 1995; Ferreiro, 1997; Gombert, 1992; Tolchinsky, 2004). There seems to be a gradual pattern going from thinking about writing as representing meaning on a more global and ideographic level (in which signs are conventional, but represent concepts or ideas), to the conception of writing as a grapho-phonological system, in which signs represent sound units. The latter stage seems to require formal reading instruction. Only a few of the illiterate adults were able to relate units of writing to units of sound, and these were the ones with some schooling. The implication for the emergent literacy models is that being able to read and write (the literacy factor) is a more decisive factor in print awareness than being young (the age factor).

A secondary aim of the present study was to inform educational practice. We see two practical implications of our research results for adult literacy teachers. It turned out that these adult illiterates were not good at recognizing the environmental print that surrounded them. As for the two models of reading acquisition, we found no supportive evidence for what might be implied by non-stage models. Although Goodman (1986) suggested that breaking whole language into abstract pieces such as syllables or phonemes makes learning to read more difficult, and Smith (1992, p. 432) stresses that learning is "spontaneous and effortless" given sufficient exposure, the outcomes of this study suggest that more than 10 or even 20 years of living in a print-rich environment brought a lot of knowledge about the functions and uses of print, but did not generate spontaneous readers or an obvious step forwards towards full print awareness. Therefore, adult literacy teachers should not take for granted that adult illiterates that enter literacy courses, even those who have been living in a print-rich environment for quite some time, already have learned to recognize environmental print only by exposure. A plausible and more fruitful practical implication might be that literacy learners need systematic and careful instructions in order to learn what to pay attention to.

The second implication is that teachers need to be precautious in the way they approach non-schooled illiterate adults. Our study reveals that educated adult readers (like we all are) look distinctly at writing and language (see also Kurvers, Van Hout, \& Vallen, 2006) than illiterates do. Teachers should be aware that many adult illiterates do not know exactly how writing maps onto speech, that they may think that only content words like 'tree' or true statements can be written, that they 
sometimes recognize a written word on the basis of visual features only, and that they do not spontaneously consider writing as something that represents units of speech. The same can be said about larger language units. Teachers should be cautious in assuming that illiterate adults share the teachers' ideas about what constitutes a sound written text.

The most important outcome of this study probably is that adult illiterates do not have a kind of naive behaviour towards the functions and uses of print (they know quite well about this), nor towards differences between notational systems. Teachers do not need to start from scratch in discussing the various functions of written language, or in carefully distinguishing writing from other visual symbols. These adult illiterates already knew about the 'outside' of the written code. But the adult illiterates in this study did not have access to the 'inside' of the written code and they need to learn in detail how the written code is mapped onto spoken language.

Open Access This article is distributed under the terms of the Creative Commons Attribution Noncommercial License which permits any noncommercial use, distribution, and reproduction in any medium, provided the original author(s) and source are credited.

\section{References}

Adams, M. (1990). Beginning to read. Thinking and learning about print. Cambridge, MA: MIT Press. Artwergen, B., Edelsky, C., \& Flores, B. (1987). Whole language: What's new? Reading Teacher, 41, $144-154$.

Barton, D. (1985). Awareness of language units in adults and children. In A. W. Ellis (Ed.), Progress in the psychology of language (Vol. 1, pp. 187-205). Hillsdale, N.J.: Lawrence Erlbaum.

Bialystok, E. (1991). Letters, sounds and symbols: Changes in children's understanding of written language. Applied Psycholinguistics, 12, 75-89.

Bialystok, E. (1995). Making concepts of print symbolic: understanding how writing represents language. First Language, 15, 317-338.

Blair, R., \& Savage, R. (2006). Name writing but not environemntal print recognition is related to lettersound knowledge and phonological awareness in pre-readers. Reading and Writing, 19, 991-1016.

Blanche-Benveniste, C. (1994). The construct of oral and written language. In L. Verhoeven (Ed.), Functional literacy. Theoretical issues and educational implications (pp. 61-74). Amsterdam: John Benjamins.

Brenneman, K., Massey, C., Machado, S. F., \& Gelman, R. (1996). Young children's plans differ for writing and drawing. Cognitive Development, 11, 397-419.

Burgess, S., Hecht, S., \& Lonigan, C. (2002). Relations of the home literacy environment (HLE) to the development of reading-related abilities: A one-year longitudinal study. Reading Research Quarterly, 37, 408-426.

Bus, A., \& Van IJzendoorn, M. (1999). Phonological awareness and early reading: A meta-analysis of experimental training studies. Journal of Educational Psychology, 9(3), 403-414.

Bus, A., Van IJzendoorn, M., \& Pellegrini, A. (1995). Joint book reading makes for success in learning to read: A meta-analysis on intergenerational transmission of literacy. Review of Educational Research, 65(1), 1-21.

Byrne, B. (1998). The foundation of literacy. The child's acquisition of the alphabetic principle. Hove East Sussex: Psychology Press.

Chall, J. S. (1999). Models of reading. In D. A. Wagner, R. L. Venezky, \& B. Street (Eds.), Literacy: An international handbook (pp. 163-166). New York: Garland Publishing.

Chartier, A. (2004). Teaching literacy: What practices, when and why? In T. Nunes \& P. Bryant (Eds.), Handbook of children's literacy (pp. 493-497). Dordrecht: Kluwer Academic Publishers.

Crone, D., \& Whitehurst, G. (1999). Age and schooling effects of emergent literacy and early reading skills. Journal of Educational Psychology, 91(4), 604-614. 
Ferreiro, E. (1978). What is written in a written sentence? A developmental answer. Journal of Education, $160,25-39$.

Ferreiro, E. (1983). The development of literacy: A complex psychological problem. In F. Coulmas \& K. Ehlich (Eds.), Writing in focus (pp. 277-290). Berlin: Mouton.

Ferreiro, E. (1985). Literacy development: A psychogenetic perspective. In D. Olson, N. Torrance, \& A. Hildyard (Eds.), Literacy, language and learning (pp. 217-228). New York: Cambridge University Press.

Ferreiro, E. (1997). The word out of (conceptual) context. In C. Pontecorvo (Ed.), Writing development. An interdisciplinary view (pp. 47-59). Amsterdam: John Benjamins.

Ferreiro, E., \& Teberosky, A. (1982). Literacy before schooling. Exeter NH: Heinemann.

Francis, N. (1999). Bilingualism, writing, and metalinguistic awareness: oral-literate interactions between first and second languages. Applied Psycholinguistics, 20, 533-561.

Gombert, J. (1992). Metalinguistic development. New York: Wheatsheaf.

Gombert, J. (1997). Metalinguistic development in first language acquisition. In L. Van Lier \& D. Corson (Eds.), Encyclopaedia of language and education. Volume 6, Knowledge about language (pp. 43-51). Dordrecht/Boston: Kluwer Academic Publishers.

Goodman, K. S. (1986). What's whole in whole language. Richmond Hill, Ontario: Scholastic.

Greenberg, D., Ehri, L., \& Perin, D. (2002). Do adult literacy students make the same word-reading and spelling errors as children matched for word-reading age? Scientific Studies of Reading, 6(3), 221-243.

Heath, S. (1983). Ways with words. Cambridge: Cambridge University Press.

Homer, B., \& Olson, D. (1999). Literacy and children's conception of words. Written Language and Literacy, 2(1), 113-140.

Hunter, C., \& Harman, D. (1979). Adult illiteracy in the United States. New York: McGraw-Hill.

Juel, C. (1991). Beginning reading. In R. Barr, M. L. Kamil, P. B. Mosenthal, \& P. David Pearson (Eds.), Handbook of reading research vol. II (pp. 759-787). New York/London: Longman.

Koch, P. (1997). Orality in literate cultures. In C. Pontecorvo (Ed.), Writing development. An interdisciplinary view (pp. 149-171). Amsterdam: John Benjamins.

Kurvers, J. (2007). Development of word recognition skills of adult L2 beginning readers. In N. Faux (Ed.), Low educated second language and literacy acquisition: Research, policy and practice (pp. 23-44). Virginia, Virginia Commonwealth University: Richmond.

Kurvers, J., \& Uri, H. (2006). Metalexical Awareness: Development, Methodology or Written Language? A cross-linguistic comparison. Journal of Psycholinguistic Research, 35(4), 353-367.

Kurvers, J., Van Hout, R., \& Vallen, T. (2006). Discovering language: metalinguistic awareness of adult illiterates. In I. Van, J. de Craats, M. Kurvers, \& Young-Scholten (Eds.), Low educated adult second language and literacy acquisition. Proceedings of the inaugural symposium (pp. 69-88). Utrecht: LOT.

Lonigan, C. J., \& Whitehurst, G. J. (1998). Relative efficacy of parent and teacher involvement in a shared-reading intervention for preschool children from low-income backgrounds. Early Childhood Research Quarterly, 17, 265-292.

Luria, A. (1976). Cognitive development: Its cultural and social foundations. Cambridge, MA: Harvard University Press.

Masonheimer, P., Drum, P., \& Ehri, L. (1984). Does environment print identification lead children into word reading? Journal of Reading Behaviour, 16, 257-271.

Morais, J., \& Kolinsky, R. (2004). The linguistic consequences of literacy. In T. Nunes \& P. Bryant (Eds.), Handbook of childrens' literacy (pp. 599-622). Dordrecht: Kluwer Academic Publishers.

Neuman, S., \& Celano, D. (2001). Access to print in low-income and middle-income communities. Reading Research Quarterly, 36(1), 8-27.

Olson, D. (1994). The world on paper. The conceptual and cognitive implications of writing and reading. Cambridge: Cambridge University Press.

Olson, D. (1997). On the relations between speech and writing. In C. Pontecorvo (Ed.), Writing development. An interdisciplinary view (pp. 3-20). Amsterdam/Philadelphia: John Benjamins.

Ravid, D., \& Tolchinsky, L. (2002). Developing linguistic literacy: a comprehensive model. Journal of Child Language, 29, 417-447.

Sabatini, J. P. (1999). Adult reading acquisition. In D. A. Wagner, R. L. Venezky, \& B. Street (Eds.), Literacy: An international handbook (pp. 49-53). New York: Garland Publishing.

Sénéchal, M., LeFevre, J. A., Smith-Chant, B. L., \& Colton, K. V. (2001). On refining theoretical models of emergent literacy: The role of empirical evidence. Journal of School Psychology, 39(5), 439-460. 
Scholes, R. (Ed.). (1993). Literacy and language analysis. Hillsdale NJ: Erlbaum.

Scholes, R., \& Willis, B. (1991). Linguistics, literacy and the intensionality of Marshall McLuhan's Western Man. In D. Olson \& N. Torrance (Eds.), Literacy and orality (pp. 215-235). Cambridge: Cambridge University Press.

Scribner, S., \& Cole, M. (1981). The psychology of literacy. Cambridge, MA: Harvard University Press. Smith, F. (1992). Learning to read: The never-ending debate. Phi Delta Kappan, 74, 432-441.

Sulzby, E., Barrnhart, J., \& Hieshima, J. (1989). Forms of writing and rereading of writing: a preliminary report. In J. Mason (Ed.), Reading and writing connections (pp. 121-146). Needham Heights, MA: Allyn \& Bacon.

Sulzby, E., \& Teale, W. (1991). Emergent literacy. In: R. Barr et al. (Eds.), Handbook of reading research (Vol. 2, pp. 727-758). New York: Longman.

Teale, W., \& Sulzby, E. (Eds.). (1987). Emergent literacy. Norwood NJ: Ablex.

Tolchinsky, L. (2004). Childhood conceptions of literacy. In T. Nunes \& P. Bryant (Eds.), Handbook of children's literacy (pp. 11-30). Dordrecht: Kluwer Academic Publishers.

Tolchinsky Landsmann, L., \& Levin, I. (1987). Writing in four-to-six year olds: representation of semantic and phonetic similarities and differences. Journal of Child Language, 14, 127-144.

Verhoeven, L. (1992). Grafementoets. In L. Verhoeven (Ed.), Drie Minuten Toets. Arnhem: Cito.

Wagner, D. (1993). Literacy, culture and development. Becoming literate in Morocco. Cambridge: Cambridge University Press.

Viise, N. (1996). A study of the spelling development of adult literacy learners compared with that of classroom children. Journal of Literacy Research, 28, 561-587.

Viise, N., \& Austin, O. (2005). Can adult low-skilled literacy learners assess and discuss their own spelling knowledge? Journal of Adolescent \& Adult Literacy, 48(5), 402-414.

Worthy, M. J., \& Viise, N. (1996). Morphological, phonological, and orthographic differences between the spelling of normally achieving children and basic literacy adults. Reading and Writing: An Interdisciplinary Journal, 8, 138-159. 